\title{
Differentiation of Infrastructure Provision of Russian Regions
}

\author{
L. Rudneva, O. Rudenok* , N. Zonova \\ Tyumen Industrial University, Tyumen, Russia \\ *Corresponding author.Email: rudenokov@tyuiu.ru
}

\begin{abstract}
Recently, quite a lot of attention has been paid to the issues of increasing the infrastructural provision of the regions of the Russian Federation. This is primarily due to the fact that overcoming infrastructural constraints is one of the ways to achieve the goal of sustainable regional development. The article discusses the issues of infrastructural security of Russian regions as one of the factors of their sustainable socio-economic and spatial development. Based on the indicators of the availability of infrastructure facilities, the degree of arrangement of regions with infrastructure facilities was studied and the features of infrastructure provision of individual regions were identified. The differentiation of the regions of the Russian Federation by the level of their infrastructural provision has been investigated. The use of the research results will make it possible to more reasonably approach the determination of the main directions for increasing the infrastructural provision of individual regions of Russia.
\end{abstract}

Keywords: Infrastructure, infrastructure provision, infrastructure components, organizational and economic system, region, sustainable regional development.

\section{INTRODUCTION}

Ensuring sustainable economic growth is a top priority for the socio-economic development of the regions of the Russian Federation. The search for new ways and dominants of regional development is becoming more and more urgent. One of the factors of regional development is an increase in the provision of infrastructure necessary to create and maintain stable economic ties and ensure the living conditions of the population both at the intraregional and interregional levels. Insufficient infrastructural provision hinders the spatial, economic and social development of regions, reduces the quality of life of the population, which determines the determining role of infrastructural provision in the implementation of regional processes. In this regard, the attention of the leadership of both the country and individual regions is focused on the problem of infrastructure security [1]. The increasing importance of infrastructural provision in the development of regions gives rise to many scientific and practical questions concerning both the assessment of the achieved level of infrastructural provision of the regions and the search for ways to increase it, and the degree of its influence on sustainable regional development.

\section{MATERIALS AND METHODS}

The theoretical and methodological basis of the study was the work of scientists and practitioners in the field of researching the problems of infrastructural provision of regions. The information base of the study was made up of statistical materials from the Federal State Statistics Service of the Russian Federation. The research was carried out using general scientific methods and techniques, such as scientific abstraction, comparative and logical analysis and synthesis, methods of analysis and others.

\section{RESULTS AND DISCUSSION}

Recently, among the necessary conditions that contribute to sustainable regional development, the provision of regions with an effectively functioning infrastructure has been increasingly singled out [1-4]. The dominant role of infrastructural provision in the socio-economic development of regions is noted by the majority of specialists dealing with regional development issues [3-9]. According to the researchers, the increase in the infrastructure provision of the regions contributes not only to the development of industrial production and the growth of GRP, but also to an increase in the level of employment and the quality of life of the population $[1,3,4,5,7,8]$. 
The regional infrastructure is a complex organizational and economic system, within which the corresponding elements of different species orientations are distinguished [8]. According to the authors of this study, the most accurate classification of the components of the regional infrastructure, depending on the functions they perform to meet the various needs of the region in creating and ensuring favorable conditions for the economy and life of the population within the territory $[7,9]$. According tp this classification, it is advisable to distinguish the following components of the regional infrastructure: housing, social, environmental, general security, transport, information, market (business) and scientific and innovative [7, 9].

The study of the infrastructural provision of the regions of Russia was carried out in two directions: 1) assessment of the degree of arrangement of regions with infrastructure facilities; 2) analysis of the differentiation of regions by the level of infrastructure provision. To characterize the infrastructural arrangement of the regions, statistical data on the presence and condition of infrastructure facilities [9, 10], presented by the Federal State Statistics Service of the Russian Federation, were used. The sample combined 82 regions of the Russian Federation, except for federal cities (St. Moscow, St. Petersburg, Sevastopol).

The development of infrastructure facilities of housing and social orientation has a significant impact on all processes taking place in the region $[10,11]$.

The study of the provision of housing infrastructure showed that the total area of residential premises, on average per one inhabitant, in 2019 on average in the country amounted to $26.3 \mathrm{~m}^{2} /$ person. The highest supply of living space is noted in the Moscow region ( $33.5 \mathrm{~m} 2 /$ person), the lowest - in the Republic of Tyva (14.2 $\mathrm{m} 2 /$ person). At the same time, the homogeneity of the regions is noted in terms of the total area of residential premises per one inhabitant - the coefficient of variation was $14.5 \%$, the coefficient of oscillation was 2.3. In total, in $2019,559 \mathrm{~m}^{2}$ of the total area of residential buildings were commissioned per 1000 people. The regions-leaders in terms of the volume of commissioning of residential buildings are the Leningrad and Moscow regions, the outsider regions include the Chukotka Autonomous Okrug, Murmansk and Magadan regions (Figure 1). At the same time, there is a strong differentiation of Russian regions in terms of the volume of commissioning of residential buildings from 26 to $1574 \mathrm{~m}^{2}$ of the total area per 1000 people. The state of the housing stock in the country as a whole can be described as satisfactory. The share of emergency housing stock in the total housing stock in the country on average was $0.7 \%$. Provision of consumer service facilities in the Russian regions in 2019. It is brewed from 126 objects per 100 thousand settlements in the Chukotka Autonomous District to 16614 objects per 100000 people in the Krasnodar Territory. The level of variation in the provision of the regions with consumer services is more than $70 \%$. The excess of the level of provision with consumer services in the Krasnodar Territory over the level of provision in the Chukotka Autonomous District is more than 130 times. On average, the provision of consumer services in the regions of Russia is 3838 objects per 100000 people according to the median indicator.

The provision of regions with social infrastructure is primarily determined by the availability and condition of healthcare and education facilities.

In terms of the level of infrastructure provision with healthcare facilities, the regions of the Russian Federation are characterized by a fairly strong differentiation (Table 1). The level of provision of outpatient clinics varies from 0.48 units per 10000 people (Republic of Bashkortostan) to 5.45 units per 10 000 people (Chukotka Autonomous District). The excess of the level of provision of outpatient clinics in the leading region over the outsider region is more than 13 times. On average, in Russia, the availability of outpatient clinics at the end of 2019 amounted to 1.38 units per 10000 people. The provision of hospital facilities ranges from 2.33 units per 100000 people (Moscow region) up to 13.32 units per 100000 people in the Magadan region. On average in Russia, the provision of hospital facilities in 2019 was 3.58 units per 100000 people. The provision of outpatient clinics and hospitals in most regions is below the Russian average.

Differentiation of Russian regions by the level of infrastructure provision with facilities for preschool and general education is also quite significant. 


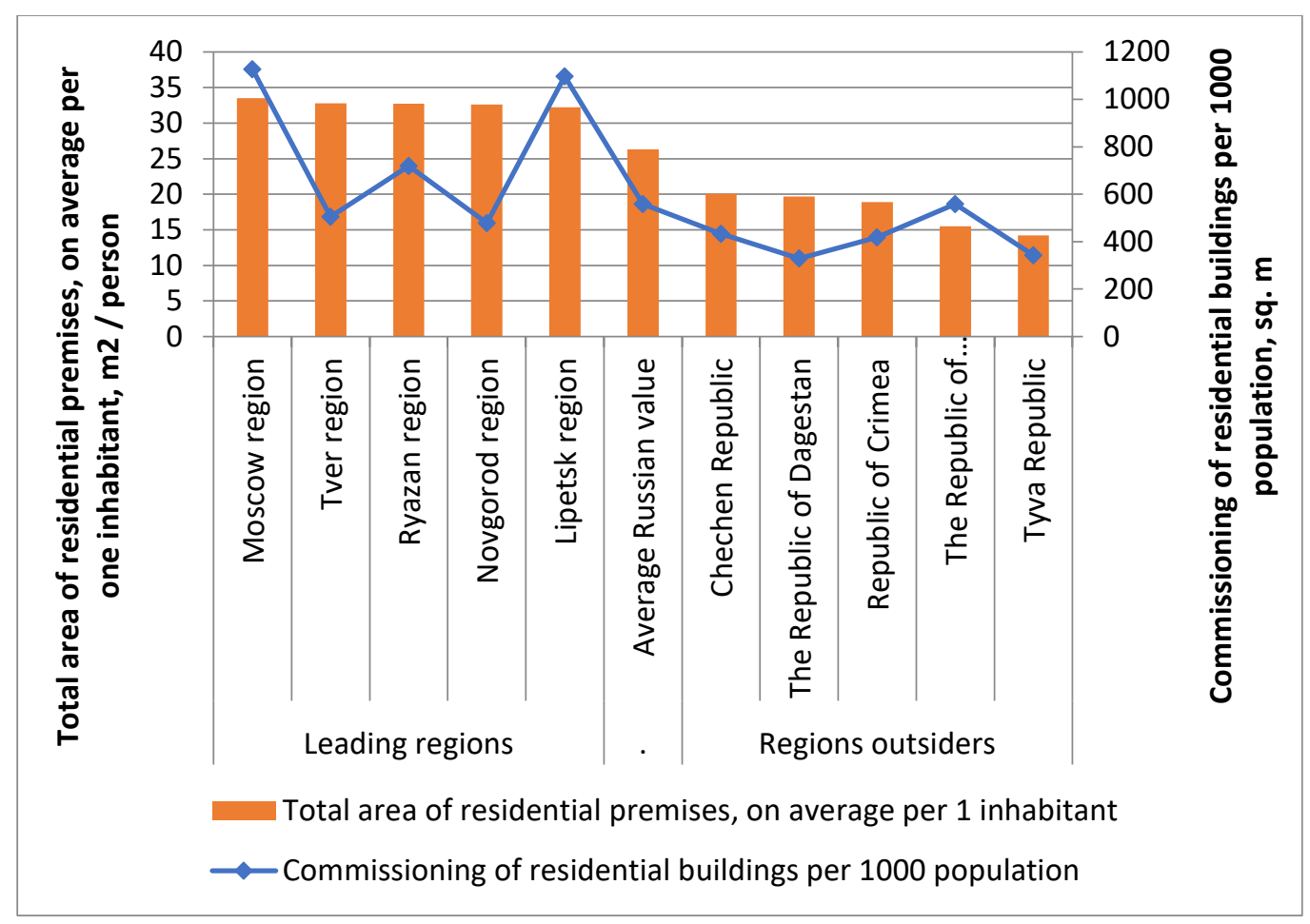

Figure 1. Distribution of regions by provision of housing infrastructure in 2019

Table 1. Distribution of regions by the level of provision of healthcare facilities in 2019

\begin{tabular}{|c|c|c|c|}
\hline \multicolumn{2}{|l|}{ Leading regions } & \multicolumn{2}{|l|}{ Outsiders } \\
\hline \multicolumn{4}{|c|}{ Provision with hospital outpatients facilities, unit/1000 people } \\
\hline Chukotka Autonomous District & 5,45 & Republic of Buryatia & 0,78 \\
\hline Magadan Region & 3,16 & Stavropol Territory & 0,69 \\
\hline Jewish Autonomous Region & 2,80 & Krasnodar Territory & 0,58 \\
\hline Republic of Karelia & 2,72 & Chechen Republic & 0,53 \\
\hline Komi Republic & 2,54 & Republic of Bashkortostan & 0,48 \\
\hline \multicolumn{4}{|l|}{ For reference: } \\
\hline \multicolumn{2}{|c|}{ Variation coefficient $-41,97 \%$} & \multicolumn{2}{|c|}{ Oscillation coefficient - 11,46 unit fraction } \\
\hline \multicolumn{4}{|c|}{ Provision with hosptal facilities, unit/1000 people } \\
\hline Kamchatka Territory & 10,16 & Republic of Tatarstan & 0,98 \\
\hline Jewish Autonomous Region & 9,94 & Republic of Bashkortostan & 0,92 \\
\hline Republic of Tyva & 8,98 & $\begin{array}{l}\text { Tyumen Region without Autonomous } \\
\text { Region }\end{array}$ & 0,85 \\
\hline Republic of Kalmykia & 8,76 & Krasnodar Territory & 0,80 \\
\hline Republic of Altay & 8,24 & Moscow Region & 0,76 \\
\hline \multicolumn{4}{|c|}{ For reference:: } \\
\hline \multicolumn{2}{|c|}{ Variation coefficient - 34,52\% } & \multicolumn{2}{|c|}{ Oscillation coefficient - 4,36 unit fraction } \\
\hline
\end{tabular}

The lowest provision of facilities for preschool and general education institutions is noted in the Tambov region (2.7 units per 10000 people), the highest provision is noted in the Republic of Sakha (Yakutia) 13.3 units per 10000 people. The gap between the regions with the most and the least amount of educational facilities is 4.9 times. At the same time, on average in Russia there are 6.3 preschool and general education institutions per 10000 people.

Regions of Russia have a high degree of differentiation in terms of the state and availability of environmental infrastructure facilities. Thus, the volume of investments in fixed assets aimed at environmental protection ranged from 8.3 million rubles in the Pskov region to 19.4 billion rubles in the Murmansk region. The gap in investment in fixed assets for environmental protection is more than 2 thousand times. The amount of funds allocated for the overhaul of environmental protection facilities in 2019 varies from 5.9 million rubles in the Chukotka Autonomous District to 2.6 billion rubles in the Republic of Tatarstan.

It should also be noted that the regions are highly differentiated in terms of the level of provision with facilities that ensure the utilization and disposal of 
production and consumption waste - the coefficient of variation in 2019 was $69.94 \%$. When studying the provision of regions with general security infrastructure facilities, it was revealed that the coverage of the population with objects of the emergency monitoring, prevention and control system ranges from $6.04 \%$ in Chuvashia to $100.0 \%$ in the Magadan region. The coverage of the population by the objects of the system of monitoring, prevention and control of emergencies in most regions exceeds the average Russian level. The provision of temporary accommodation for the population varies from 0.01 units per 10000 people in the Tula region to 9.2 units per 10000 people in the Republic of Sakha (Yakutia). The provision of potentially dangerous objects with local warning systems on average in Russia is $81.5 \%$. It has been established that in most regions there is one hundred percent provision of potentially dangerous objects with local warning systems.

The presence of a developed transport infrastructure in the region is of great importance for the sustainable development of the regions. On average in Russia, the level of provision with a road transport network is 236.5 $\mathrm{km}$ per $1000 \mathrm{~km}^{2}$ of the territory, the average level of provision with a railway transport network is $171.3 \mathrm{~km}$ per $1000 \mathrm{~km}^{2}$. The Republic of Ingushetia, the Moscow and Belgorod Regions are the most provided with a motor transport network, outsider regions include regions with a completely undeveloped motor transport network - Yamalo-Nenets, Nenets and Chukotka Autonomous District (Figure 2).

The gap between the regions with the most and the least secured road transport network is more than 700 times. The Belgorod Region is the leader in the length of highways with a high-quality structural part $(90.21 \%)$. The level of provision of regions with a railway transport network ranges from $577 \mathrm{~km}$. per 1000 $\mathrm{km}^{2}$ in the Moscow region up to $2 \mathrm{~km}$ per $1000 \mathrm{~km}^{2}$ of the territory in Yakutia. In several regions of Russia, there is no railway transport network at all due to the peculiarities of the geographic location. The level of security of the transport network and the length of highways with high-quality execution of the structural part in most regions of the Russian Federation exceed the average Russian values.

In terms of the level of provision of information infrastructure, the regions of Russia are characterized by rather low differentiation. On average in the country, the number of connected subscriber devices for mobile communications in 2019 amounted to 2,109.8 units per 1000 people. The leader in the number of connected mobile subscriber devices is the Krasnodar Territory with an indicator value of 2548.7 units per 1000 people, the most lagging region is the Republic of Crimea (629.8 units per 1000 people). There is also a high level of provision of subscribers with fixed and mobile broadband Internet access - the number of active subscribers of mobile broadband Internet access on average in Russia in 2019 amounted to 96.4 units per 100 people. The leader among the regions in terms of the level of Internet access is the Yamalo-Nenets Autonomous District (130.5 units per 100 people), the lagging regions include the Republics of Tyva, Dagestan and Ingushetia due to the peculiarity of their geographic location.

Market infrastructure plays an important role in ensuring the development of regions. The provision of the regions with market infrastructure facilities is characterized by significant differentiation. The highest level of availability of trade objects with a sufficiently large margin from other regions is noted in the Republic of Crimea, and catering facilities - in the Magadan region (2.47 units/1000 people). The leader in the provision of gas stations is the Republic of Khakassia with the level of provision of this type of infrastructure facilities at 4.71 units per 10000 people. Among the lagging regions in terms of market infrastructure provision are the Chuvash Republic, Tatarstan, KhantyMansiysk Autonomous District-Yugra, the regions of the North Caucasus Federal District, Novosibirsk and Murmansk regions (Table 2). The lowest level of provision with trade and public catering facilities is observed in Ingushetia, which ranks second among the leading regions in terms of the level of gas station provision. The provision with credit and financial institutions in Russia on average in 2019 amounted to 0.81 units per 100000 people. The regions with a high level of provision of credit and financial institutions include the Nenets Autonomous District, Sakhalin and Chelyabinsk regions. A low level of provision with credit and financial institutions is noted in the Bryansk, Leningrad and Moscow regions.

The assessment of the availability of scientific and innovative infrastructure facilities revealed that on average in Russia the number of organizations performing research and development in 2019 amounted to 2.76 units per 100000 people, and the share of organizations implementing technological innovations amounted to $21.6 \%$ of the number surveyed. Regions with a high level of availability of scientific organizations are Chukotka and Nenets Autonomous Districts, Tomsk Region. It is important to note that the Tomsk Region belongs to the leading regions in terms of the provision of organizations that carried out technological innovations (Figure

$3)$. 


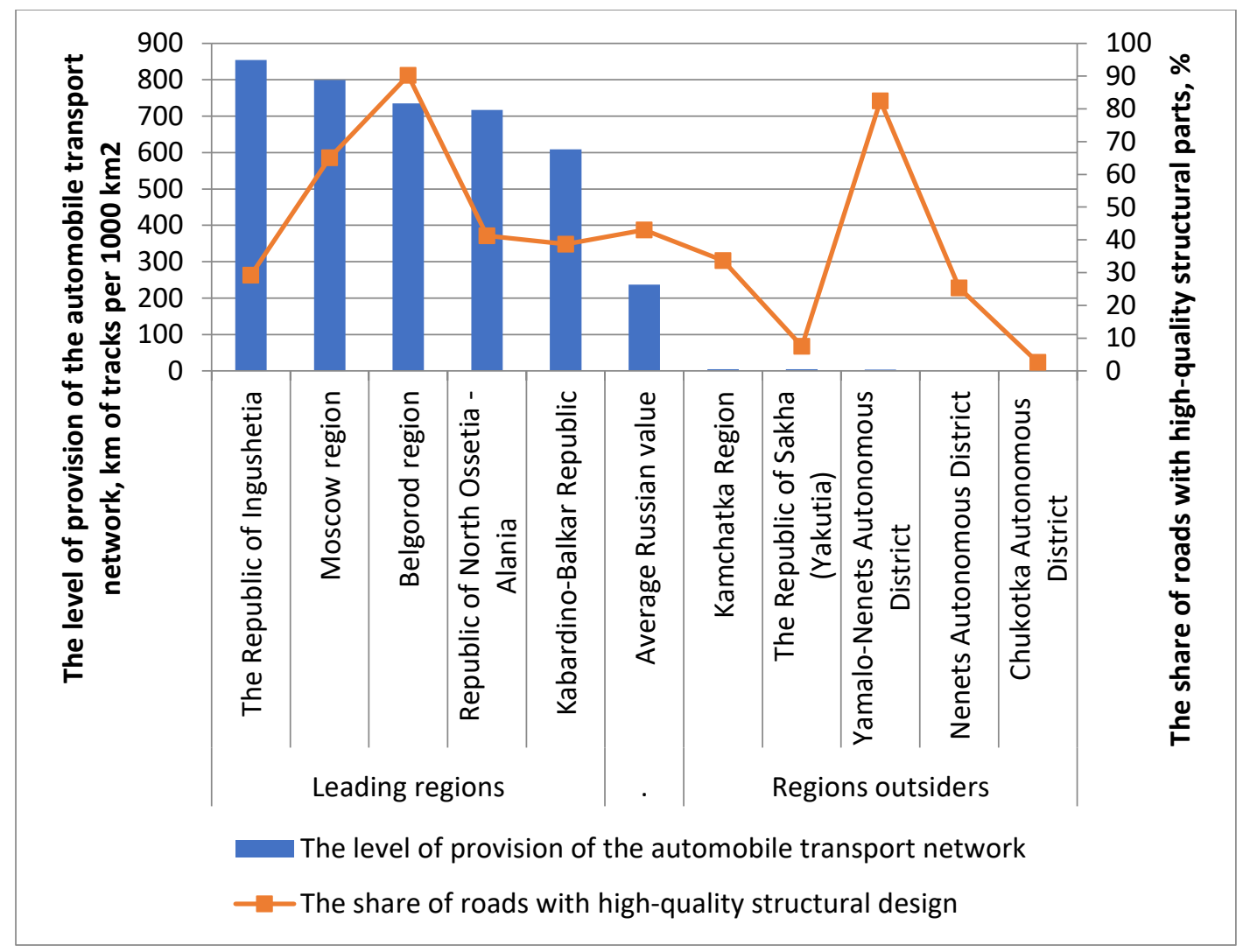

Figure 2. Distribution of regions in terms of provision of the road transport network in 2019

Table 2. Distribution of regions by level of market infrastructure provision in 2019

\begin{tabular}{|c|c|c|c|}
\hline \multicolumn{2}{|l|}{ Leading regions } & \multicolumn{2}{|l|}{ Outsiders } \\
\hline \multicolumn{4}{|c|}{ Provision with trade facilities, unit/1000 people } \\
\hline Republic of Crimea & 14,05 & Chuvash Republic & 5,44 \\
\hline Kamchatka Territory & 11,84 & Tatar Republic & 5,34 \\
\hline Ulyanovsk Region & 11,51 & Chechen Republic & 5,10 \\
\hline Rostov Region & 11,28 & $\begin{array}{l}\text { Khanty-Manssiysk Autonomous District } \\
\text { - Yugra }\end{array}$ & 5,08 \\
\hline Novgorod Region & 11,27 & Republic of Ingishetia & 4,77 \\
\hline \multicolumn{4}{|c|}{ Provision with catering facilities, unit/1000 people } \\
\hline Magadan Region & 2,47 & Karachaevo-Cherkessk Republic & 0,98 \\
\hline Komi Republic & 2,32 & Chechen Republic & 0,92 \\
\hline Altay Republic & 2,32 & Republic of Dagestan & 0,85 \\
\hline Republic of Crimea & 2,09 & Republic of North Osetia - Alania & 0,80 \\
\hline Republic of Buryatia & 1,98 & Republic of Ingishetia & 0,76 \\
\hline
\end{tabular}




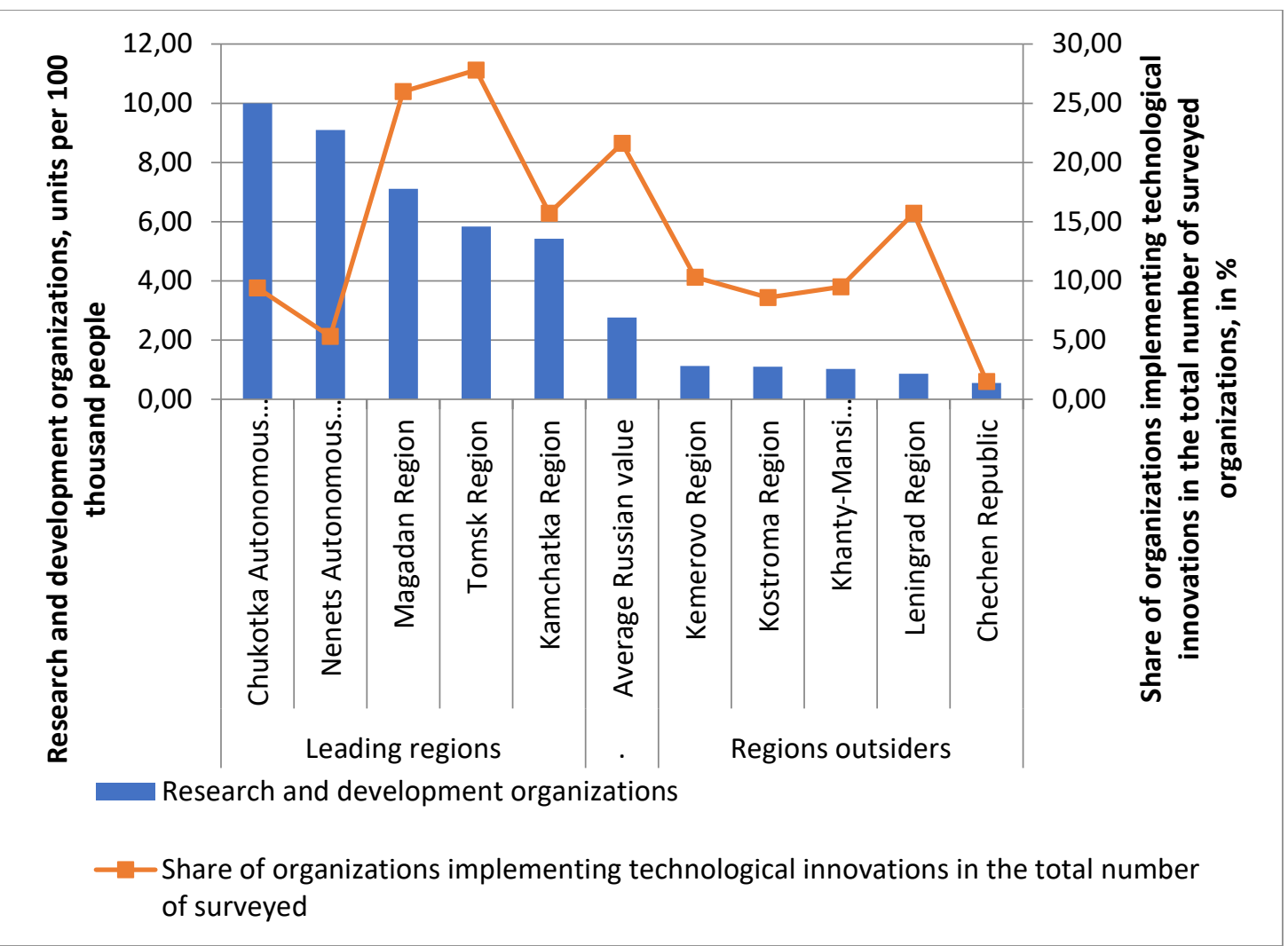

Figure 3. Distribution of regions by provision of innovative infrastructure facilities in 2019

In terms of the level of provision of organizations that carried out technological innovations, the leading regions also include the Republic of Mordovia, the Chuvash Republic, Rostov and Ryazan regions, which are regions with an average level of provision of organizations that carried out research and development. The regions with a low level of provision of scientific organizations include the Khanty-Mansi Autonomous District-Yugra, the Leningrad Region, and the Chechen Republic. At the same time, the Chechen Republic has the lowest level of provision of organizations implementing technological innovations.

\section{CONCLUSIONS}

Summarizing the above, it can be stated that the regions of Russia have a fairly high degree of differentiation in the presence and condition of infrastructure facilities of different functionality. The greatest difference between Russian regions is observed in the level of provision with transport infrastructure, insignificant - in the level of provision of housing and household and information infrastructure facilities. The existing level of infrastructure provision in the regions is due to a number of reasons. The main ones are: the lack of a targeted Infrastructure Development Strategy in a number of regions that meets regional needs; the low proportion of investments in the development of individual infrastructure components, including at the expense of budgetary and attracted funds; the lack of interest of private business in attracting funds for the development of regional infrastructure.

Increasing the infrastructural security of the regions and strengthening their positions is possible only in the case of expanding the practice of introducing contractual financing mechanisms and identifying strategic priorities within the framework of targeted regional development programs aimed at achieving a more sustainable correspondence of infrastructural security to the level of regional development.

\section{REFERENCES}

[1] O. S. Pchelintsev, M. M. Minchenko, Regional infrastructure as an economic growth condition. In: Studies on Russian Economic Development, 15(6) (2004) pp. 559-566.

[2] M. M. Minchenko, Territorial development of the Russian Federation: Pressing problems of resource support. In: Studies on Russian Economic Development, 15(3) (2004) pp. 266-274.

[3] M. K. Biktemirova, T. A. Svetovtceva, L. G. Rudenko, S. V. Kiselev, T. V. Nikonova, L. V. Semenova, L. E. Fatikhova, The Social Infrastructure Services in the Context of Economic Growth Factors. In: Mediterranean Journal of Social Sciences, 6(2 S3) (2015) p. 260. DOI: https://doi.org/10.5901/mjss.2015.v6n2s3p260. 
[4] R. Crescenzi, A. Rodríguez-Pose, Infrastructure and regional growth in the European Union. In: Papers in Regional Science, 91(3) (2012) pp. 487513. DOI: https://doi.org/10.1111/j.14355957.2012.00439.x.

[5] Yu. G. Myslyakova, S. N. Kotlyarova, N. A. Matushkina, Genetic Approach to Assessing the Infrastructure Coherence of an Industrial Region. In: Economy of region, 17(3) (2021) pp. 784-798. DOI: https://doi.org/10.17059/ekon.reg.2021-3-5.

[6] N. S. Malafeev, I. V. Baskakova, Empirical Evaluation of the Contribution of Infrastructure Capital to the Development of the Region (Based on the Data of Ural Economic Region). In: Economy of Region, 13(3) (2017) pp. 777-788. DOI: https://doi.org/10.17059/2017-3-11.

[7] J. A. Mescheryakova, O. V. Rudenok, Infrastructure security as a factor of regional development. In: 10th International Conference "Science and Technology", SCIEURO 2018 pp. 121-137.

[8] S. N. Kotlyarova, Conceptual approaches to assessing the impact of infrastructure on regional development. In: Regional Economics and Management: electronic scientific journal, 3 (31) (1999). http://eee-region.ru/article/3103/.

[9] L. N. Rudnea, O. V. Rudenok, Yu. A. Meshcheryakova, Methodical Approach to Assessing the Infrastructural Provision of Regions. Scientific Review: Theory and Practice, 7 (2018) pp. 155-170.

[10] P. A. Pykhov, T. O. Kashina, Infrastructure Security of the Ural Regions: Assessment Technique and Diagnostic Results. In: Economy of Region, 3 (2015) pp. 66-77. DOI: https://doi.org/10.17059/2015-3-6.

[11] V. S. Antonyuk, I. V. Danilova, S. A. Mitelman, A. Z. Bulikeyeva, Regional Social Infrastructure Management as the Instrument for Improving the Quality of Life in the Ural Federal District. In: Economy of Region, 3 (2015) pp. 53-66. DOI: https://doi.org/10.17059/2015-3-5. 